Article

\title{
Sociology in Global Environmental Governance? Neoliberalism, Protectionism and the Methyl Bromide Controversy in the Montreal Protocol
}

\author{
Brian J. Gareau \\ Department of Sociology, and the International Studies Program, Boston College, 140 Commonwealth Avenue, \\ Chestnut Hill, MA 02467, USA; gareau@bc.edu; Tel.: +1-617-552-8148
}

Received: 14 August 2017; Accepted: 4 October 2017; Published: 10 October 2017

\begin{abstract}
Sociological studies of global agriculture need to pay close attention to the protectionist aspects of neoliberalism at the global scale of environmental governance. With agri-food studies in the social sciences broadening interrogations of the impact of neoliberalism on agri-food systems and their alternatives, investigating global environmental governance (GEG) will help reveal its impacts on the global environment, global science/knowledge, and the potential emergence of ecologically sensible alternatives. It is argued here that as agri-food studies of neoliberalism sharpen the focus on these dimensions the widespread consequences of protectionism of US agri-industry in GEG will become better understood, and the solutions more readily identifiable. This paper illustrates how the delayed phase out of the toxic substance methyl bromide in the Montreal Protocol exemplifies the degree to which the US agri-industry may be protected at the global scale of environmental governance, thus prolonging the transition to ozone-friendly alternatives. Additionally, it is clear that protectionism has had a significant impact on the dissemination and interpretation of science/knowledge of methyl bromide and its alternatives. Revealing the role that protectionism plays more broadly in the agriculture/environmental governance interface, and its oftentimes negative impacts on science and potential alternatives, can shed light on how protectionism can be made to serve ends that are at odds with environmental protection.
\end{abstract}

Keywords: global environmental governance; Montreal Protocol; methyl bromide; neoliberalism; protectionism; science; strawberries; sociology

\section{Introduction}

Sociological studies of global agriculture need to pay close attention to the protectionist aspects of neoliberalism at the global scale of environmental governance. With US agri-food studies broadening interrogations of the impact of neoliberalism on conventional agri-food systems and their alternatives, investigating global environmental governance (GEG) will steadily reveal its impacts on the global environment, science/knowledge, and the potential for alternative agriculture worldwide. I argue that future agri-food studies of neoliberalism should focus research efforts on these aspects because the consequences of protectionism of US agri-industry in GEG, in particular, have been negative on multiple levels. A clear example of the problematic issues arising from the insertion of agri-food into GEG can be found in the delayed methyl bromide phase-out of the Montreal Protocol on Substances that Deplete the Ozone Layer, hereinafter the Montreal Protocol.

The Montreal Protocol is oftentimes, and rightfully, described as the most successful global treaty designed to protect the environment of all time, and in this case, to protect the stratospheric ozone layer [1]. Utilizing the precautionary principle, the global community agreed that measures needed to be taken to avert the effects of a depleting ozone layer on humans and natural ecosystems (For recent discussion and analysis of the Montreal Protocol, see special issue of the Journal of Environmental Studies 
and Sciences (5:2), in particular: [2-5]). While the science of ozone depletion has become extremely robust, and our knowledge of atmospheric chemistry is much more certain, in the early days of ozone protection it was necessary to place the risks of a depleting ozone layer ahead of existing uncertainties in the science, to take action prior to fully comprehending the effects that substances created by humans were having on the Earth's protective layer [6,7]. Through the Montreal Protocol, chlorofluorcarbons, hydrochloroflurocarbons, methyl bromide, and other ozone-depleting substances have all been put on phase-out schedules designed to lead to their eventual extinction. Thus, with the guidance of capable leadership, including scientists, government officials, corporate buy-in, and vested civil society groups, the Montreal Protocol was ratified in 1987 and entered into force on 1 January 1989, and has steadily been strengthened via amendments and decisions designed to speed up ozone layer recovery [8,9].

While global climate change presents a great deal of uncertainty with regards to predicting recovery rates of the ozone layer, the Montreal Protocol has indeed worked: "The Earth's protective ozone layer is well on track to recovery in the next few decades ... The Montreal Protocol has now reduced (ozone-depleting substance) emissions by more than $90 \%$ " ([10] quoted in [1], p. 113). In fact, since some ozone-depleting substances are also greenhouse gases, Montreal Protocol successes have led to greenhouse gas emissions reductions "five times larger than the annual emissions reductions target for the first commitment period (2008-2012) of the Kyoto Protocol" ([10] quoted in [1], p. 113). Small wonder that the Montreal Protocol is often written off as a completed success story. Yet, as David Downie writes, "this is still no time for complacency;" There are lessons to be learned from some of the harder phase-out processes, processes perhaps best investigated with a sociological lens [5].

Global environmental governance is an area that has received relatively little attention from sociologists when compared to other scales of environmental governance (relative to other disciplines in the social sciences as well, such as political science and human geography). Yet, what studies exist have brought fresh insights, contributing alternate ways of understanding social ties (e.g., "social capital") that lead to (or inhibit) successful treaty-making [9], macro-level theories of power, social control, and political economic influence that oftentimes extend beyond treaty confines as well as the investigative scopes of "regime studies" in the political sciences [11-18], and the efficacy of social movements in shaping global environmental treaty outcomes [19-21]. Importantly, a growing body of literature in global sociology and the social sciences in general investigates the effects that protectionism of particular industries and economies is having on global governance and environmental protection in particular [14-25]. This article contributes to this literature in its concern for the deleterious effects that protection of US agri-industry via the delayed the phase-out of the toxic substance methyl bromide-a neurotoxin used as a pre-plant fumigant and for quarantine treatment, and an ozone-depleting substance-had on ozone layer protection during the 2000s. It draws on the sociological literature on power and social control in order to show how actors at one scale (in this case, actors operating in the agrarian networks of California) can influence outcomes at the global scale. The paper joins a growing raft of scholarship investigating protectionism in a neoliberal global agri-food system.

\section{Protectionism in a Neoliberal World?}

Neoliberalism is almost a hackneyed term at this point, but it is used by scholars for good reasons. In the case of global environmental governance, its usage helps us understand the central role that the market and profit motives have come to play even here, a realm quite literally designed to protect ecological conditions from destruction caused by human activities, including economic activity. As Ciplet and Roberts put it,

"[N]eoliberal environmental governance can be understood as a more fully implemented stage of liberalism, with the expansion of the market, economic rationality and private gain as increasingly identified as the primary goals and sole mechanisms for the protection of public and environmental goods. In the process, governance is insulated from normative interventions which extend beyond the well-defined institutional bounds of market-oriented consideration. This has the effect of 
empowering those that are deemed to possess expert knowledge, including market actors, while often marginalizing lay people and their context-specific concerns." ([11], pp. 150-151)

Therefore, global environmental governance has turned increasingly toward market-based conditions in order to gauge how protection of the environment should rightly occur. Here we can see why research in the social sciences on the "commodification of nature" has grown, as have critiques of this approach to environmental governance as it tends to lead to the displacement of local peoples and the privatization of natural resources [26-29]. Yet, at the same time, we can understand neoliberalization as a process by which certain forms of knowledge and powerful actors are protected. In this way, neoliberalism is a contrasting process that calls for marketization whilst protecting the economic conditions and ideologies of certain groups. This can lead to a disconnect between the short-term interests of well-connected actors in GEG processes and the long-term goals of environmental protection, a temporal disconnect. Additionally, there is a growing social disconnect that has shifted instances of GEG towards the protection of a small groups of stakeholders whilst endangering society [11,30-34].

Yet the protection of certain market actors does not happen equally across countries. Scholarship in global sociology has studied the uneven effects of neoliberalism as a process of opening markets in the global south to transnational corporations in the north, but not necessarily vice versa. The same levels of inequity are felt in GEG, where powerful countries have the leverage to shape governance in ways that support their interests over those of less powerful countries (For a glimpse into the unequal exchanges among state actors found in GEG from sociological, geographical, and environmental law perspectives, respectively, see [35-37]).

The protection of national economies can often conflict with the goals of GEG. For instance, protectionism of US agri-industry has stalled progress in some heretofore relatively successful global environmental agreements, such as the Montreal Protocol, the subject of the case study below. But protection of the US economy is also a well-known reason for lack of buy-in on global climate agreements over the years [38]. Oftentimes touted for its precautionary measures to protect the ozone layer (i.e., the chlorofluorocarbon (CFC) phase-out case), the Montreal Protocol experienced a virtual standstill for several years in efforts to eliminate ozone-depleting methyl bromide, a pre-plant fumigant used heavily in US strawberry production (during my research period from 2003 to 2008), and was eventually phased out completely in 2016. Additionally, protectionism has arguably manipulated the dissemination and interpretation of ozone science/knowledge and inhibited the emergence of ozone-friendly alternatives to methyl bromide, as the case below illustrates. Moreover, US protection of its agri-industry deterred the emergence and extension of more ecologically-oriented alternatives, such as organic strawberries. These are serious issues affecting the planet that are currently rather understudied in the sociology of global agriculture. (For some notable exceptions, see [15,39]. In a broader context, complementary studies of labor and agriculture in global governance, as well as GEG and biotechnology, see notably [40-43].)

Agri-food scholars have begun investigating "neoliberal" ways in which problems associated with conventional agriculture are being handled in the US and worldwide. As a hegemonic political discourse, neoliberalism is seen as shaping the opportunities made available to reformulate agriculture. Models popular in Europe, and growingly so in the US, such as "multifunctionality," and locally based initiatives such as right-to-farm laws, agricultural zoning, farm-to-school programs, and purchase of development rights programs are explored for their potential to curtail the negative impacts of neoliberalism in agriculture [44-47]. US researchers such as Patricia Allen, Julie Guthman [48,49], and Jill Harrison [50] have illustrated how these models can become heavily constrained by the neoliberal doctrines of "free trade", individual responsibility, consumerism, and the utilization of market mechanisms to determine agricultural policy implementation. They have shown how these doctrines can become engrained in the projects of social movements and the everyday practice of individuals. Thus, we can think of neoliberalism as representing a great challenge facing alternative agriculture schemes today (See also [39,51-53]). 
Of course, neoliberalism never exists as an ideal type, but rather, is observed occurring unevenly in empirical life based on specific contexts/relations (e.g., [54,55]). In a Geoforum issue devoted to neoliberalization of food, for instance, Harrison shows how the regulation of pesticides has gradually decreased in the US since the 1970s, and funding of alternative forms of pest management has been all but eliminated [50]. Such nation-state responsibilities have largely devolved to the state level, where local regulation of pesticides is often contradictory to local needs to remain competitive. Yet, the coexistence of "free markets" and other neoliberal tenets and protectionism are quite pronounced in agriculture. As Guthman notes,

"On the one hand, agriculture and food sectors have been subject to some of the most intense attempts at neoliberalization-from the privatization of land and water rights, to the use of free trade agreements to dismantle national-level food safety regulations, to the protracted dismantling of food-oriented (and other) entitlement programs ... On the other hand, neoliberalization appears quite limited in this sphere. Notwithstanding the General Agreement on Trade and Tariffs (GATT) provisions regarding agriculture, in both the EU and US, domestic food sectors remain economically protected..." [56]

In some respects, this contradiction seems simply to reflect the disjuncture between neoliberal rhetoric and "actually existing neoliberalisms" that others have observed. In other words, while neoliberal policies are embedded in agriculture worldwide, such policies have often occurred as manifestations of protectionism in US agriculture, both locally and at the global scale of environmental governance. In the US, for example, much research and extension is still provided through land grant institutions for agriculture. Thus, it is important to emphasize the phrase "actually-existing neoliberalism" is especially salient to the agri-food sector, because it is a sector oftentimes protected from market forces, yet increasingly that level of protection is diminishing for less-powerful global actors $[57,58]$. For instance, in addition to the liberalizing global trade agreements like the General Agreement on Trade and Tariffs (GATT) and the World Trade Organization (WTO), some global environmental agreements remain highly protectionist of various US agri-food sectors, albeit with increasing pressure to liberalize coming from less-developed, yet powerful, nations [58]. Such protectionism has found its way into an important instance of global environmental governance, the Montreal Protocol. The consequences, while contained by the methyl bromide controversy itself, have been rather deleterious for ozone diplomacy, ozone science/knowledge, and the potential emergence of ecologically sensible alternatives in US agriculture.

My arguments here are based mainly on my observations of agriculture operating at the global scale of environmental governance from a global environmental sociological perspective [3,4,14,30-34]. GEG is designed to seek ways to make social organization more ecologically sustainable. In the neoliberal era of GEG, however, scholars recognize that it has often been made to maximize profit of North-based agri-industrial firms and other corporate actors, improving ecological conditions only secondarily (For examples of neoliberalization affects in various areas of GEG, see [12,59-63]). GEG incorporates a multifaceted decision-making process involving international organizations, governments, scientific experts, corporate interests, non-governmental organizations (NGOs) and other pressure groups representing civil society in a relatively decentralized way. However, studies in critical geography, sociology, and elsewhere reveal that such forms of governance often end up supporting powerful countries and their corporations at the expense of the environment, fair trade, and the well-being of the global south (Some notable pioneering cases include $[15,29,64,65]$ ).

The stalled phase-out of methyl bromide, a pre-plant fumigant used in US conventional strawberry production up until 2016, which was called for predominately by the US in the Montreal Protocol, is a case in point. The case typifies the degree to which the agriculture of powerful countries is protected at the global scale in the neoliberal era of GEG. The case, however, also illustrates the impact that such protectionism can have on the dissemination of science/knowledge in GEG, and the potential for the emergence of ecologically sensible alternatives to conventional agriculture. Below, I will present the methyl bromide case in order to illustrate the links between US agri-industry protectionism, 
neoliberalism, ozone science/knowledge, and ozone-friendly agri-food alternatives in GEG. In this review of the delayed methyl bromide phase-out, my aim is to provide a social science perspective for this special issue on the fate of toxic pollutants in the environment, and encourage the reader to explore the science/policy interface of GEG and the Montreal Protocol in particular by accessing the works referenced herein. In conclusion, I will suggest a possible way forward from a sociological perspective.

\section{Strawberries, Protectionism, and the Montreal Protocol}

In 2005, at the height of the methyl bromide controversy, California, a leading strawberry producing state, provided almost 90 per cent of US strawberries on roughly 34,000 acres. Worth over $\$ 1$ billion in 2005, it was California's 7th most valuable crop. For decades, fumigating fields with methyl bromide allowed for dense planting of strawberries in large acreages over many seasons without an increase in disease and little need for crop rotations. Thus, methyl bromide was recognized as a key technology in California production systems $[66,67]$. Alternative strawberry production systems, however, have been researched, implemented, and proven successful in certain scenarios despite minimal funding. For instance, by 2003, organic strawberries represented 4 per cent of total California strawberry acreage. The expansion of organic strawberry production is likely to remain limited since a large shift to organics would likely result in a price drop unable to compensate for increased production costs. Nonetheless, research investment has been made in organic strawberry production, and it is possible that the economics of production may improve as research expands $[68,69]$.

In 1992, member states adhering to the Montreal Protocol agreed to a mandated systematic phase-out of methyl bromide. The protocol ordered the phase-out of methyl bromide in 2005 for industrialized countries and in 2015 for less-developed countries. But methyl bromide remained in use (albeit in consistently reduced quantities) in the US strawberry production up until 2016. How? At the 9th Meeting of the Parties to the Montreal Protocol (MOP) in 1997, Decision IX/6 was ratified, allowing "critical use exemptions" for qualified uses of methyl bromide. At the first Extraordinary MOP in 2003, the US received critical use exemptions to the phase-out totaling almost 10,000 metric tons, larger than all other exemption requests combined. While the amount reflected the fact that US strawberry growers and their acreage were far greater than that of other industrialized countries, the size of the exemptions came as a shock to the global community and created a great deal of controversy [14].

In and around MOP meetings, research was being conducted in order to determine what effect a methyl bromide-free world would have on the US. Investigating that research helps us unveil how protectionism contributes to a neoliberal environmental governance milieu, and how scientific knowledge may be disseminated in ways that support that protection. For instance, several studies had been conducted in order to forecast the impact that reductions in methyl bromide would have on the US strawberry industry and the California strawberry production complex in particular. While some studies made calculations based on the abrupt and complete elimination of methyl bromide [70-72], others provided estimates based on its gradual withdrawal, an approach more closely aligned with how the phase-out process was to be conducted via Montreal Protocol guidelines [73]. The abrupt reduction studies forecasted the costs to be quite high due to township caps and other regulatory restrictions on alternatives, while the gradual reduction studies reported the costs to be minimal as markets for alternatives would improve and growers would "learn by doing" strawberry farming with increasingly less methyl bromide over time (The issue, of course, is more complicated than this. Methyl iodide, a chemical long anticipated by growers to replace methyl bromide, was removed from the market due to public concern with its toxic effects [74]. Additionally, California buffer zone regulations, technical constraints faced by some farmers due to farmland geography, and financial costs associated with switching to alternatives were all real issues facing farmers and the California Strawberry Commission that represented them at the Montreal Protocol meetings. For further discussion of these issues, see $[66,70-72,75-78])$. While both assessments clusters were backed by sound research, the varied approaches meant that the US and its constituents had a range of possibilities with which to challenge the methyl bromide phase-out. 
The critical use exemptions marked a "neoliberal turn" in Montreal Protocol policy-making, where the technical and economic impact of alternatives on the individual user (i.e., strawberry growers in California) of methyl bromide was the main concern. In contrast, exemptions to the famed chlorofluorocarbon (CFC) phase-out under the same protocol were granted only if the CFC use was deemed essential to the general welfare of all society [14,30,34]. US methyl bromide critical use exemptions caused intense debate among global stakeholders at the protocol meetings. Countries in the global south, such as the Dominican Republic, suggested that the extension of methyl bromide via the CUE was an attempt to lengthen the "period of domination" of US agri-industry in this sector, while a whole host of countries in Latin American and Africa noted that the critical use exemption requests from the US in particular made it impossible for them to discuss procedures for the upcoming methyl bromide phase-out in the global south. Industrialized countries, such as Japan, believed that the CUEs would be "misleading to [its] farmers," who were advised to seek lower nominations. The European Union, by far the greatest advocate for minimal CUE nominations in the industrialized world, provided the lengthiest exchange of argument with the US (For an extensive discussion of these exchanges among nation-states as they unfolded in the years 2003-2008, see [14]).

Participant observation at "Meetings of the Parties", "Open-ended Working Group" (OEWG) meetings, and "Extraordinary Meetings" of the Montreal Protocol for five years (2003-2008), interviewing scientists, state delegates, and NGO representatives revealed how the US exerted its power to prolong its use of methyl bromide to protect California strawberry growers from global competition. Yet, it is also clear that US protectionism has had a significant impact of the dissemination and interpretation of science/knowledge of methyl bromide and its alternatives [14,31].

At the 2003 OEWG, the Methyl Bromide Technical Options Committee (MBTOC), the scientific body that informs the protocol about the feasibility of methyl bromide alternatives, recommended rejecting the US's requests for methyl bromide in strawberry production for field uses. The MBTOC reported that over two hundred studies worldwide showed excellent results with the implementation of methyl bromide alternatives. The US delegation, however, did not accept the MBTOC assessment. The US chose to highlight the studies that predicted a costly reduction as opposed to those that were the focus of the global scientific community, studies that saw very little cost associated with the phase-out for strawberry growers-the key actors of concern [77]. They highlighted as well how the local economic and geographic conditions made the application of alternatives more difficult than the MBTOC study acknowledged. At the 15th MOP in 2003, the US all but threatened to withdraw from the treaty if its exemptions were not accepted:

"II]f our exemption request is not approved ... such an outcome could shatter the fragile coalition within the United States that enables us to make progress in international bodies. I urge delegates to avoid such an outcome."

(US Delegation, 15th Meeting of the Parties to the Montreal Protocol, Nairobi, Kenya, 10-14 November 2003, recorded notes)

The Natural Resources Defense Council (NRDC), an environmental watch-dog organization representing more than two million members, described the US request for continuing the use of methyl bromide as "embarrassing," and reminded parties of the scientific findings:

"Of the current critical use requests ... there is really only one that, despite having achieved a 70 percent reduction, is now seeking to reverse itself, and increase its use and production of methyl bromide. The MBTOC ... report specifically finds that there isn't adequate support for two-thirds of the [US critical use exemption] request. .. It is a question of whether you are going to remain true to the agreement you adopted in 1997, or whether one country will have the opportunity to reverse the phase-out and reverse its commitments."

(Doniger, D., Natural Resources Defense Council (NRDC), 15th Meeting of the Parties to the Montreal Protocol, Nairobi, Kenya, 10-14 November 2003, recorded notes.) 
Only a few months later, at the first "Extraordinary Meeting of the Parties" in 2004, a meeting designed to resolve the extraordinary critical use exemption request from the US, the MBTOC changed its recommendation, and urged the parties to permit the US exemption:

"We would certainly wish to support the suggestion of ... the U.S. delegation ... We would recommend to parties to grant the [critical use exemptions]."

(MBTOC presentation, 1st Extraordinary Meeting of the Parties to the Montreal Protocol, Montreal, Quebec, Canada, 24-26 March 2004, recorded notes.)

This outcome was seen as extremely unjust by the European Union, members of MBTOC, and environmental NGOs. The European Union expressed serious concern with the MBTOC recommendation:

"It is a most unusual process that we are going through, where we hear the MBTOC co-Chair recommending as though it were some kind of auction system!"

(EU Delegation, 1st Extraordinary Meeting of the Parties to the Montreal Protocol, Montreal, Quebec, Canada, 24-26 March 2004, recorded notes. This explanation of California's strawberry production complex is the product of a research team investigating global competition in strawberry production.)

An example of neoliberal rhetoric, the US claimed that global competition would be made "unnatural" without methyl bromide. Decision IX/6 of the Montreal Protocol expresses that alternatives to methyl bromide must not have a negative impact on the marketability of any individual user of methyl bromide (The full statement reads: "the lack of availability of methyl bromide for that use would result in a significant market disruption; and there are no technically and economically feasible alternatives or substitutes available to the user that are acceptable from the standpoint of environment and public health and are suitable to the crops and circumstances of the nomination" [79]. Here, the debate regarding what constitutes a technically and economically feasible alternative is what divided opinions on the critical use exemption request from the US.).

Additionally, it was the California Strawberry Commission, a semi-public interest group, which provided the market-based argument against the global scientific claims of MBTOC. Here, the "stakeholders" themselves were providing a voice to groups in California that required representation in a neoliberal context (It is important to note that the NRDC is also a stakeholder, one directly involved in the protocol deliberations, but one that represented the spectrum of environmental protection, not agri-industry actors). However, the case is more complicated than this. Neoliberalism is about protectionism as much as marketability. The Montreal Protocol relies on the "good faith" of nation-states and their industrial counterparts. It requires that they provide scientific assessment panels like the MBTOC with the best information available, and that they make the best efforts possible to phase out ozone-depleting substances. This takes us back to the primacy of protectionism of US agri-industry.

This is not to say that California strawberry growers did not have legitimate reasons to be worried about the challenges of switching to alternatives, alternatives that could have technological and economic impacts. What is important to understand from a sociological perspective is the ways in which interpretations of those impacts enter the global scale of environmental governance and serve to legitimate some actors, concerns, and forms of knowledge over others [33]. The methyl bromide phase-out was extended well beyond the phase-out with the use of CUEs by use of certain scientific findings over others just as relevant from a methodological perspective. Yet, the future would show that the ex-ante studies projecting minimal costs to strawberry growers in a methyl bromide-free world were by far the most accurate. Mayfield and Norman, for example, provide the most comprehensive assessment of this outcome, finding little if any indication that the California strawberry industry has been negatively affected by the methyl bromide phase-out. Rather, the strawberry industry had grown whilst the methyl bromide phase-out gradually occurred at the behest of the US, not the more 
rapid reduction originally supported by the global community [78]. Mayfield and Norman state, "Contrary to ex-ante industry claims, the years of declining methyl bromide use have been years of rising yields, acreage, exports, revenues and market share for California growers, even when faced with a global recession and increased imports from Mexican growers who retain the right to use the chemical [until 2015] under the Protocol" ([78], p. 93). Here we see the agri-industry pushing the Montreal Protocol closer towards protection that it historically had been forced to move. By inserting language that allowed parties to demonstrate market impacts as opposed to social welfare, several hundred strawberry growers were capable of stalling the methyl bromide phase-out until all risks could be minimized for the transition. This is a clear demonstration of the precautionary principle being severed from the protocol and protection or particular subjects being grafted in its place [80].

The methyl bromide case demonstrates the impact that protectionism can have on the interpretation and dissemination of science/knowledge, which likewise impacts the potential emergence of alternatives. With the US, and California in particular, situated as the dominant site of scientific knowledge in strawberry production, it is unsurprising that good faith efforts allowed for the continuance of the status quo in strawberry production standards for so long, with alternatives to methyl bromide difficult to defend [81]. It also turned out that the bulk of remaining methyl bromide sat in stockpiles in the US. For several years, the NRDC argued that US stockpiles of methyl bromide were large enough for critical use exemption needs. At the 24th OEWG in 2004, the Environmental Investigation Agency (EIA) and the NRDC presented photos and video of these stockpiles of methyl bromide stored in railroad cars and small canisters totaling almost 6000 metric tons. These stockpiles were not considered by the protocol when exemptions are granted. These interventions by NGOs led to significant discussion in protocol plenary, suggesting that exposing protectionism might lead to changes in GEG.

The MBTOC, the global experts on methyl bromide and its alternatives, reported that methyl bromide alternatives for strawberry production work very well. The NRDC even revealed that there are ample stockpiles of methyl bromide in the US, making its request to produce less clear. The issue appeared to have less to do with the viability of alternatives than with the competition facing the US from Chinese, European, and Mexican strawberry production platforms. In only five years, China had become a major global player in strawberry production, selling in high volumes in Europe, Asia, and the US. Due to the late development of its strawberry industry, China produces strawberries without relying on methyl bromide, making up for lower yields with more acreage and cheaper labor. While China increases its exports, California strawberry growers struggle to enter both Europe and China's growing markets. This "emerging superpower" is feared to be an economic threat to US strawberry production by US growers, agri-chemical companies, and the US government $[31,32,75]$. Meanwhile, science/knowledge poised to legitimize alternatives to methyl bromide remain rather excluded from any large-scale implementation in the US. Yet, even amid these pressures, the California strawberry industry has seen robust growth, bringing us back to the protective nature of agri-food in GEG. While local conditions might have made the transition to alternatives difficult, it seems clear that the knowledge base of these conditions were more contested than was presented by the US.

\section{Conclusions}

The case of methyl bromide in the Montreal Protocol shows that the rhetoric of neoliberalism does not match the behavior of governments that continue to protect their vital interests. While this point is not unique (as other governments often exhibit the same behaviors), the implications of such actions for effective GEG regarding science/knowledge production and ecologically sensible alternatives to conventional agriculture are relatively understudied in the sociology of global agriculture. The US threatened to leave what it considers to be "one of the most important international agreements in place today" unless it received more methyl bromide. In the case of the Montreal Protocol, such stalling could negatively impact the ozone layer, which is necessary for life on earth, in a moment when ozone layer recovery is less certain due to the chaotic effects of global climate change. The solution, however, 
is not to invoke a more absolute "actually existing neoliberalism" [54]. The solution, rather, is to further reveal the dangerous paradox of neoliberal rhetoric versus the actual behavior of powerful nation-states. This paradox contains serious implications when the protectionist policies and practices of US agri-industry subvert ozone science/knowledge and socially/ecologically sensible alternatives. For example, at the national scale, US protectionism has deterred the development of non-chemical forms of strawberry production.

The insertion of agri-food concerns into the Montreal Protocol also provides clear insight into the different models at work in global environmental policy, models that become most pronounced when agro-industry is involved. First, the precautionary principle is a pillar of successful GEG, and it had been allowed to remain a pillar in the Montreal Protocol until the methyl bromide phase-out. This could be one reason for the growing divide between the US and Europe on the methyl bromide phase-out, global climate change, trade in transboundary wastes, and other major environmental issues - two global powers that worked together to make the Montreal Protocol a global success. US environmental policy is not usually based on this paradigm and instead utilizes a cost-benefit framework to determine the tradeoffs associated with various policy options, even if a high cost option is ultimately chosen [82,83]. The US model also focuses on scientific evidence of the known or demonstrated risks or effects of a pollutant and not just the possibility of harm, which again marks a move away from the precautionary principle. Consequently, when the anticipated costs are very high in the short run due to the inability to quickly find alternatives, the US chooses to phase in a policy more slowly, thus confirming its approach to the methyl bromide phase-out. Eventually, the industry is regulated, but gradually and given more flexibility that what we would expect with a precaution-centric approach to cost-benefit assessments. Viewed through this lens, we can understand why the US' took such a protective action when negotiating the methyl bromide phase out as it meshes with how environmental policy proceeds domestically. What is important to note here is that some interpretations of the costs, those which were more extreme in the short-term, took precedence in global negotiations.

Another area that deserves mention is that of alternatives to ozone-depleting substances, alternatives that often have significant negative local impacts. There is a great deal of work yet to be done to achieve ecologically-oriented strawberry production. The conventional alternatives to methyl bromide might not deplete the ozone layer but certainly have negative local effects. Two examples are 1,3-Dichloropropene, which has a township cap due to its toxicity and ability to persist in water, and chloropicrin, a war gas, both of which have been the subject of pesticide drift [84]. Another example is methyl iodide, which was approved for use in strawberry fields in 2008, a highly effective alternative to methyl bromide for strawberry fumigation. Due to its toxicity and high reactivity (it is a carcinogen and neurotoxin that can mutate DNA), however, chemists worldwide, including five Nobel laureates, petitioned the US Environmental Protection Agency to reject methyl iodide as a replacement for methyl bromide, which consequently led to its removal from the marketplace in 2012 (See also [85,86]). As noted above, ecologically-oriented alternatives, such as organic strawberries, are available but poorly funded and poorly promoted [74,87]. Revealing the protectionist aspects of US agri-industry in GEG, and its impacts of the global environment, science/knowledge, and the potential of alternatives might shed light on how protectionism could be made to serve different ends.

Alternative developments in strawberry production are not only at a market disadvantage, they are up against a sector shielded from global competition by the nation-state. As recent agri-food studies of neoliberalism have noted, alternative movements that opt for free market and voluntarist solutions will seldom prevail in such a scenario. In order to achieve more socially equitable and ecologically sensible conditions, alternative movements must engage with both state and non-state targets [22]. We need to develop research paradigms that are interdisciplinary so that we can unpack how industry and nation-states affect and use scientific knowledge, and we must do so while remaining cognizant of the broader tendencies of the capitalist system that shapes (and hampers) possibilities in agriculture. Agri-food studies have succeeded in providing the latter but need to work harder on 
incorporating the former into research agendas. Importantly, we must reveal viable alternatives and the deeply embedded social institutional dynamics that impede their development at the scale of global environmental governance.

Acknowledgments: Special thanks to Wally Goldfrank for his support of this research. He is sorely missed. I am grateful for the comments from three anonymous reviewers for helping make this a better manuscript.

Conflicts of Interest: The author declares no conflict of interest.

\section{References}

1. Canan, P.; Reichman, N.; Andersen, S.O.; Gareau, B.J. Introduction to the Special Issue on Ozone Layer Protection and Climate Change: The Extraordinary Experience of Building the Montreal Protocol, Lessons Learned, and Hopes for Future Climate Change Efforts. J. Environ. Stud. Sci. 2015, 5, 111-121. [CrossRef]

2. Gonzalez, M.; Taddonio, K.N.; Sherman, N.J. The Montreal Protocol: How today's successes offer a pathway to the future. J. Environ. Stud. Sci. 2015, 5, 122-129. [CrossRef]

3. Gareau, B.J. A Critical Review of the Successful CFC Phase-out versus the Delayed Methyl Bromide Phase-out in the Montreal Protocol. Int. Environ. Agreem. Politics Law Econ. 2010, 10, 209-231. [CrossRef]

4. Gareau, B.J. Lessons from the Montreal Protocol Delay in Phasing Out Methyl Bromide. J. Environ. Stud. Sci. 2015, 5, 163-168. [CrossRef]

5. Downie, D. Still No Time for Complacency: Evaluating the Ongoing Success and Continued Challenge of Global Ozone Policy. J. Environ. Stud. Sci. 2015, 5, 187-194. [CrossRef]

6. Gao, S. Managing Short-Lived Climate Forcers in Curbing Climate Change: An Atmospheric Chemistry Synopsis. J. Environ. Stud. Sci. 2015, 5, 130-137. [CrossRef]

7. Parson, E. Protecting the Ozone Layer: Science and Strategy; Oxford University Press: New York, NY, USA, 2003.

8. Andersen, S.O.; Sarma, K.M.; Sinclair, L. Protecting the Ozone Layer: The United Nations History; Earthscan Publications: London, UK, 2002.

9. Canan, P.; Reichman, N. Ozone Connections: Expert Networks in Global Environmental Governance; Greenleaf: Sheffield, UK, 2002.

10. World Meteorological Organization (WMO). Assessment for Decisions Makers: Scientific Assessment of Stratospheric Ozone: 2014; World Meteorological Organization, Global Ozone Research and Monitoring Project-Report No. 56; WMO: Geneva, Switzerland, 2014.

11. Ciplet, D.; Roberts, J.T. Climate Change and the Transition to Neoliberal Environmental Governance. Glob. Environ. Chang. 2017, 46, 148-156. [CrossRef]

12. Ciplet, D.; Roberts, J.T.; Khan, M. Power in a Warming World: The New Global Politics of Climate Change and the Remaking of Environmental Inequality; MIT Press: Cambridge, MA, USA, 2015.

13. Ciplet, D. Contesting Climate Injustice: Transnational Advocacy Network Struggles for Rights in UN Climate Change Politics. Glob. Environ. Politics 2014, 14, 75-96. [CrossRef]

14. Gareau, B.J. From Precaution to Profit: Contemporary Challenges to Environmental Protection in the Montreal Protocol; Yale University Press: New Haven, CT, USA; London, UK, 2013.

15. Goldman, M. Imperial Nature: The World Bank and Struggles for Social Justice in the Age of Globalization; Yale University Press: New Haven, CT, USA, 2005.

16. Marco, G.; Roberts, J.T. A Compromise to Break the Climate Impasse. Nat. Clim. Chang. 2014, 4, 543-549. [CrossRef]

17. Shorette, K.; Henderson, K.; Sommer, J.M.; Longhofer, W. World Society and the Natural Environment. Sociol. Compass 2017. [CrossRef]

18. Brechin, S.R.; Ness, G.D. Looking Back at the Gap: International Organizations as Organizations Twenty-Five Years Later. J. Int. Organ. Stud. 2013, 4, 14-39.

19. Fisher, D.R.; Galli, A.M. Civil Society Engagement in Climate Governance: Between Collaboration and Conflict. In Research Handbook on Climate Governance; Backstrand, K., Lovbrand, E., Eds.; Edward Elgar Publishing: Northampton, MA, USA, 2015; pp. 297-309.

20. Widick, R.; Foran, J. Whose Utopia? Our Utopia! Competing Visions of the Future at the UN Climate Talks. Nat. Cult. 2016, 12, 296-321. [CrossRef] 
21. Foran, J.; Ellis, C.; Gray, S. At the COP: Global Climate Justice Youth Speak Out. Available online: https:/ / cloudup.com/cVI5W-xg33M (accessed on 14 August 2017).

22. Cordner, A.; Brown, P. A Multisector Alliance Approach to Environmental Social Movements: Flame Retardants and Chemical Reform in the United States. Environ. Sociol. 2015, 1, 69-79.

23. Edge, S.; Eyles, J. Contested Governmentalities: NGO Enrollment and Influence Over Chemical Risk Governance Rationales and Practices. Environ. Policy Gov. 2015, 25, 188-200. [CrossRef]

24. Jorgenson, A.K. Five Points on Sociology, PEWS and Climate Change. J. World-Syst. Res. 2015, 21, $270-275$. [CrossRef]

25. Longhofer, W.; Schofer, E.; Miric, N.; Frank, D.J. NGOs, INGOs, and Environmental Policy Reform, 1970-2010. Soc. Forces 2016, 94, 1743-1768. [CrossRef]

26. Bakker, K. Neoliberalizing Nature? Market Environmentalism in Water Supply in England and Wales. Ann. Assoc. Am. Geogr. 2005, 95, 542-565. [CrossRef]

27. Bakker, K. The Commons Versus the Commodity: Alter-globalization, Anti-privatization and the Human Right to Water in the Global South. Antipode 2007, 39, 430-455. [CrossRef]

28. Corson, C. Shifting Environmental Governance in a Neoliberal World: US AID for Conservation. Antipode 2010, 42, 576-602. [CrossRef]

29. McCarthy, J. Privatizing Conditions of Production: Trade Agreements and Environmental Governance. Geoforum 2004, 35, 269-393. [CrossRef]

30. DuPuis, E.M.; Gareau, B.J. Neoliberal Knowledge: The Decline of Technocracy and the Weakening of the Montreal Protocol. Soc. Sci. Q. 2008, 89, 1212-1229. [CrossRef]

31. Gareau, B.J. Dangerous Holes in Global Environmental Governance: The Roles of Neoliberal Discourse, Science, and California Agriculture in the Montreal Protocol. Antipode 2008, 40, 102-130. [CrossRef]

32. Gareau, B.J. Theorizing Environmental Governance of the World System: Global Political Economy Theory and Some Applications to Stratospheric Ozone Politics. J. World-Syst. Res. 2012, 18, 187-210. [CrossRef]

33. Gareau, B.J. The Limited Influence of Global Civil Society: International Environmental Non-governmental Organisations and the Methyl Bromide Controversy in the Montreal Protocol. Environ. Politics 2012, 21, 88-107. [CrossRef]

34. Gareau, B.J.; DuPuis, E.M. From Public to Private Global Environmental Governance: Lessons from the Montreal Protocol's Stalled Methyl Bromide Phase-out. Environ. Plan. A 2009, 41, 2305-2323. [CrossRef]

35. Beckfield, J. Inequality in the World Polity: The Structure of International Organization. Am. Sociol. Rev. 2003, 68, 401-424. [CrossRef]

36. Okereke, C. Global Justice and Neoliberal Environmental Governance: Ethics, Sustainable Development and International Co-Operation; Routledge: New York, NY, USA, 2008.

37. Speth, J.G. The Bridge at the End of the World: Capitalism, the Environment, and Crossing from Crisis to Sustainability; Yale University Press: New Haven, CT, USA; London, UK, 2008.

38. Nordhaus, W.D.; Boyer, J. Warming the World; MIT Press: Cambridge, MA, USA, 2000.

39. McMichael, P. Food Regimes and Agrarian Questions; Fernwood Press: Halifax, NS, Canada, 2013.

40. Clapp, J. Hunger in the Balance: The New Politics of International Food Aid; Cornell University Press: Ithaca, NY, USA, 2012.

41. Clapp, J.; Doris, F. (Eds.) Corporate Power in Global Agrifood Governance; MIT Press: Cambridge, MA, USA, 2009.

42. Agrawal, A.; Wollenberg, E.; Persha, L. Governing Agriculture-forest Landscapes for Climate Change Mitigation. Glob. Environ. Chang. 2014, 29, 270-280. [CrossRef]

43. Newell, P.; Taylor, O.G. Contested Landscapes: The Global Political Economy of Climate Smart Agriculture. J. Peasant Stud. 2017. [CrossRef]

44. Pfeffer, M.; Lapping, M.B. Farmland Preservation, Development Rights and the Theory of the Growth Machine: The View of Planners. J. Rural Stud. 1994, 10, 233-248. [CrossRef]

45. Wilson, G.A. From Productivism to Post-productivism ... and Back Again? Exploring the (Un)changed Natural and Mental Landscapes of European Agriculture. Trans. Inst. Br. Geogr. 2001, 26, 77-102. [CrossRef]

46. Hollander, G.M. Agricultural Trade Liberalization, Multifunctionality, and Sugar in the South Florida Landscape. Geoforum 2004, 35, 299-312. [CrossRef]

47. Potter, C.; Burney, J. Agricultural Multifunctionality in the WTO: Legitimate Non-trade Concern of Disguised Protectionism? J. Rural Stud. 2002, 18, 35-47. [CrossRef] 
48. Allen, P.; Guthman, J. From "Old School" to "Farm-to-School": Neoliberalization from the Ground Up. Agric. Hum. Values 2006, 23, 401-415. [CrossRef]

49. Guthman, J. Neoliberalism and the Making of Food Politics in California. Geoforum 2008, 39, 1171-1183. [CrossRef]

50. Harrison, J. Abandoned Bodies and Spaces of Sacrifice: Pesticide Drift Activism and the Contestation of Neoliberal Environmental Politics in California. Geoforum 2008, 39, 1197-1214. [CrossRef]

51. McMichael, P. (Ed.) The Global Restructuring of Agro-Food Systems; Cornell University Press: Ithaca, NY, USA, 1994.

52. McMichael, P. Global Food Politics. In Hungry for Profit; Magdoff, F., Foster, J.B., Buttel, F., Eds.; Monthly Review Press: New York, NY, USA, 2000.

53. Bonanno, A. From Columbus to ConAgra: The Globalization of Agriculture and Food; University of Kansas Press: Lawrence, KS, USA, 1994.

54. Brenner, N.; Theodore, N. Cities and the Geographies of "Actually Existing Neoliberalism". Antipode 2002, 34, 349-379. [CrossRef]

55. Castree, N. From Neoliberalism to Neoliberalisation: Consolations, Confusions, and Necessary Illusions. Environ. Plan. A 2006, 38, 1-6. [CrossRef]

56. Stoneman, S. Julie Guthman, On Globalization, Neoliberalism, Obesity, Local Food and Education. Politics and Culture, 2009. Available online: https:/ / politicsandculture.org/2010/10/27/an-interview-withjulie-guthman/ (accessed on 14 August 2017).

57. Chorev, N. Remaking U.S. Trade Policy: From Protectionism to Globalization; Cornell University Press: Ithaca, NY, USA, 2007.

58. Hopewell, K. Breaking the WTO: How Emerging Powers Disrupted the Neoliberal Project; Stanford University Press: Redwood City, CA, USA, 2016.

59. Clapp, J. Toxic Exports; Cornell University Press: Ithaca, NY, USA, 2001.

60. Lucier, C.A.; Gareau, B.J. Obstacles to Preserving Precaution and Equity in Global Hazardous Waste Regulation: An Analysis of Contested Knowledge in the Basel Convention. Int. Environ. Agreem. 2016, 16, 493-508. [CrossRef]

61. Mansfield, B. Rules of Privatization: Contradictions in Neoliberal Regulation of North Pacific Fisheries. Ann. Assoc. Am. Geogr. 2004, 94, 565-584. [CrossRef]

62. Okereke, C. Global Justice and Neoliberal Environmental Governance: Sustainable Development, Ethics and International Co-Operation; Routledge Research in Environmental Politics; Routledge: London, UK, 2010.

63. Olson, K.; Gareau, B.J. Hydro/Power? Politics, Discourse and Neoliberalization in Laos's Hydroelectric Development. Sociol. Dev. 2017, forthcoming.

64. McCarthy, J. The Financial Crisis and Environmental Governance 'After' Neoliberalism. Tijdschrift voor Economische en Sociale Geografie 2012, 103, 180-195. [CrossRef]

65. McCarthy, J.; Prudham, S. Neoliberal Nature and the Nature of Neoliberalism. Geoforum 2004, 35, $275-283$. [CrossRef]

66. Norman, C.S. Potential Impacts of Imposing Methyl Bromide Phaseout on US Strawberry Growers: A Case Study of a Nomination for a Critical Use Exemption under the Montreal Protocol. J. Environ. Manag. 2005, 75, 167-176. [CrossRef] [PubMed]

67. Goodhue, R.E.; Fennimore, S.A.; Ajwa, H.A. The Economic Importance of Methyl Bromide: Does the California Strawberry Industry Qualify for a Critical Use Exemption from the Methyl Bromide Ban? Rev. Agric. Econ. 2005, 27, 198-211. [CrossRef]

68. Shennan, C.; Muramoto, J.; Mazzola, M.; Butler, D.; Rosskoph, E.; Kokalis-Burelle, N.; Momma, K.; Kobara, Y.; Lamers, J. Anaerobic Soil Disinfestation for Soil Borne Disease Control in Strawberry and Vegetable Systems: Current Knowledge and Future Directions. ISHS Acta Hortic. 2014, 1044, 165-175. [CrossRef]

69. Shennan, C.; Muramoto, J.; Koike, S.; Baird, G.; Fennimore, S.; Samtani, J.; Bolda, M.; Dara, S.; Daugovish, O.; Lazarovits, G.; et al. Anaerobic Soil Disinfestation is an Alternative to Soil Fumigation for Control of Some Soilborne Pathogens in Strawberry Production. Plant Pathol. 2017. [CrossRef]

70. Carpenter, J.; Gianessi, L.; Lynch, L. The Economic Impact of the Scheduled U.S. Phase-Out of Methyl Bromide; National Center for Food and Agricultural Policy: Washington, DC, USA, 2000.

71. Carpenter, J.; Lynch, L.; Trout, T. Township Limits on 1,3-D Will Impact Adjustment to Methyl Bromide Phase-out. Calif. Agric. 2001, 55, 12-18. [CrossRef] 
72. VanSickle, J.; NaLampang, S. The Impact of the Phase Out of Methyl Bromide on the U.S. Vegetable Industry; Policy Brief 02-1; International Agricultural Trade and Policy Center, University of Florida: Gainesville, FL, USA, 2002.

73. UNEP (United Nations Environmental Programme). Montreal Protocol on Substances That Deplete the Ozone Layer: Technology and Economic Assessment Panel; UNEP: Nairobi, Kenya, 1997.

74. Guthman, J. Lives Versus Livelihoods? Deepening the Regulatory Debates on Soil Fumigants in California's Strawberry Industry. Antipode 2017, 49, 86-105. [CrossRef]

75. Carter, C.A.; Chalfant, J.A.; Goodhue, R.E.; Han, F.M.; DeSantis, M. The Methyl Bromide Ban: Economic Impacts on the California Strawberry Industry. Rev. Agric. Econ. 2005, 27, 181-197. [CrossRef]

76. Carter, C.A.; Chalfant, J.A.; Goodhue, R.E. China's Strawberry Industry: An Emerging Competitor for California? ARE Update 2005, 9, 7-15.

77. DeCanio, S.J.; Norman, C.S. Economics of the "Critical Use" of Methyl Bromide under the Montreal Protocol. Contemp. Econ. Policy 2005, 23, 376-393.

78. Mayfield, E.N.; Norman, C.S. Moving Away from Methyl Bromide: Political Economy of Pesticide Transition for California Strawberries since 2004. J. Environ. Manag. 2012, 106, 93-101. [CrossRef] [PubMed]

79. UNEP. Handbook for the Montreal Protocol on Substances that Deplete the Ozone Layer, 7th ed. 2006. Available online: http:/ / unep.ch/ozone/publications/handbooks/mp_handbook_2006.pdf (accessed on 14 August 2017).

80. Steel, D. Philosophy and the Precautionary Principle: Science, Evidence, and Environmental Policy; Cambridge University Press: Cambridge, UK, 2015.

81. Gareau, B.J.; Borrego, J. Global Environmental Governance, Competition, and Sustainability in Global Agriculture. In Handbook of World-Systems Analysis; Babones, S., Chase-Dunn, C., Eds.; Routledge: New York, NY, USA, 2012; pp. 357-365.

82. Sunstein, C.R. Cost-Benefit Analysis and the Environment. Ethics 2005, 115, 351-385. [CrossRef]

83. Executive Order 12866 of September 30, 1993. Regulatory Planning and Review. Federal Register Vol. 58, No. 190. Available online: https:/ / www.archives.gov/files/federal-register/executive-orders/pdf/12866. pdf (accessed on 14 August 2017).

84. Harrison, J.L. Pesticide Drift and the Pursuit of Environmental Justice; MIT Press: Cambridge, MA, USA, 2011.

85. Cone, M. EPA Approves New Pesticide Despite Scientists' Concerns; LA Times: Los Angeles, CA, USA, 6 October 2007.

86. Guthman, J.; Brown, S. Midas' Not-So-Golden Touch: On the Demise of Methyl Iodide as a Soil Fumigant in California. J. Environ. Policy Plan. 2016, 18, 324-341. [CrossRef]

87. Wolverton, A. Retrospective Evaluation of Costs Associated with Methyl Bromide Critical Use Exemptions for Open Field Strawberries in California. J. Benefit-Cost Anal. 2014, 5, 225-257. [CrossRef] 